\title{
A Case of IgG4-related Disease With Bone Marrow Involvement: Bone Marrow Findings and Flow Cytometric Immunophenotyping of Plasma Cells
}

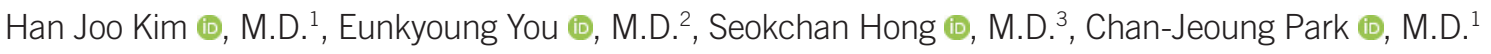 \\ ${ }^{1}$ Department of Laboratory Medicine, Asan Medical Center, University of Ulsan College of Medicine, Seoul, Korea; ${ }^{2}$ Department of Laboratory Medicine, Inje \\ University College of Medicine, Busan Baik Hospital, Busan, Korea; ${ }^{3}$ Department of Laboratory Medicine, Division of Rheumatology, Department of Internal \\ Medicine, Asan Medical Center, University of Ulsan College of Medicine, Seoul, Korea
}

\section{Dear Editor,}

Immunoglobulin G4 (IgG4)-related disease (lgG4-RD), an immune-mediated fibro-inflammatory disorder, is diagnosed based on tissue biopsies [1-3]. The key features include dense lymphoplasmacytic infiltration rich in lgG4-positive plasma cells, storiform fibrosis, obliterative phlebitis, and mild-to-moderate eosinophil infiltration. IgG4 immunohistochemical (IHC) staining is needed to confirm the diagnosis in the presence of these features. IgG4-RD can invade almost all organs including the kidneys, lungs, and aorta and frequently form a tumefactive mass that destroys the involved organs. Comprehensive criteria for IgG4-RD diagnosis were suggested by a Japanese group in 2012: high serum IgG concentration (>1.35 g/L), increased numbers of IgG4-positive cells ( $>10$ cells/high-power field [HPF]), and IgG4/lgG-positive cell ratio of $>40 \%$ [4]. Blood plasmablasts have been reported as biomarkers for diagnosis and assessment of treatment response. IgG4-RD patients have elevated plasmablast concentrations in the peripheral blood (PB; median: 4,698 cells/mL, range: 610-79,524 cells/mL) [5]. Plasmablasts with $\mathrm{CD} 19^{\text {low }} \mathrm{CD} 38^{+} \mathrm{CD} 2 \mathrm{O}^{-} \mathrm{CD} 27^{+}$have been measured by flow cytometric immunophenotyping [6].

Although lgG4-RD is well known for variable organ involvement, only three cases of bone marrow (BM) involvement have been reported [7-9]. Hwang, et al. [9] reported a case in Korea in 2019; however, neither PB nor BM plasma cell flow cytometry was conducted. We present a case of IgG4-RD with BM involvement and demonstrate the usefulness of flow cytometric immunophenotyping of plasma cells in PB and BM aspirates in IgG4-RD diagnosis. The Institutional Review Board of Asan Medical Center, Seoul, Korea (S2020-1248-0001) approved this study and waived the need for informed consent from the patient.

A 63-year-old man with renal failure was diagnosed as having IgG4-RD a year ago, confirmed by a kidney biopsy (tubulointerstitial nephritis with increased interstitial lymphoplasmacytic infiltration and >30 lgG4-positive plasma cells/HPF). He had visited the outpatient clinic complaining of abdominal pain and a skin rash that had developed one month earlier. The computed tomography scan showed multiple lymphadenopathies, and the torso positron emission tomography images revealed hyperactive BM. Blood tests revealed leukocytosis, thrombocytopenia, marked eosinophilia (51\% on white blood cell [WBC] differential count), and rare nucleated red blood cells (1/100 WBCs). Total serum IgG and IgG4 concentrations were increased (Table 1). PB smear showed poikilocytosis and rouleaux formation (Fig. 1A). Serum protein electrophoresis indicated polyclonal gam-
Received: March 31, 2020

Revision received: May 19, 2020

Accepted: September 24, 2020

Corresponding author: Chan-Jeoung Park, M.D.

Department of Laboratory Medicine, University of Ulsan, College of Medicine and Asan Medical Center, 88 Olympic-ro 43-gil, Songpa-gu, Seoul 05505, Korea

Tel: +82-2-3010-4508, Fax: +82-2-478-0884

E-mail: cjpark@amc.seoul.kr 
Table 1. Laboratory findings

\begin{tabular}{lccc}
\hline & Results & Reference range & Unit \\
\hline WBC & 16.5 & $4-10$ & $10^{9} / \mathrm{L}$ \\
Hb & 122 & $130-160$ & $\mathrm{~g} / \mathrm{L}$ \\
Platelet & 45 & $150-350$ & $10^{9} / \mathrm{L}$ \\
Total protein & 74 & $60-80$ & $\mathrm{~g} / \mathrm{L}$ \\
Albumin & 20 & $35-52$ & $\mathrm{~g} / \mathrm{L}$ \\
AST & 1.5 & $0-0.7$ & $\mu \mathrm{kat} / \mathrm{L}$ \\
ALT & 1.05 & $0-0.7$ & $\mu \mathrm{kat} / \mathrm{L}$ \\
Alkaline phosphatase & 12.4 & $0.7-2.0$ & $\mu \mathrm{kat} / \mathrm{L}$ \\
Total bilirubin & 102.6 & $3.4-20.5$ & $\mu \mathrm{mol} / \mathrm{L}$ \\
Direct bilirubin & 99.2 & $0-8.6$ & $\mu \mathrm{mol} / \mathrm{L}$ \\
Sodium & 133 & $135-145$ & $\mathrm{mmol} / \mathrm{L}$ \\
Potassium & 4.1 & $3.5-5.1$ & $\mathrm{mmol} / \mathrm{L}$ \\
Chloride & 93 & $98-110$ & $\mathrm{mmol} / \mathrm{L}$ \\
Creatinine & 636.5 & $61.9-123.8$ & $\mu \mathrm{mol} / \mathrm{L}$ \\
BUN & 10.4 & $3.6-9.3$ & $\mathrm{mmol} / \mathrm{L}$ \\
Amylase & 1.4 & $0.5-1.8$ & $\mu \mathrm{kat} / \mathrm{L}$ \\
Lipase & 1.4 & $0.2-1.0$ & $\mu \mathrm{kat} / \mathrm{L}$ \\
CK & 1.2 & $0.8-4.2$ & $\mu \mathrm{kat} / \mathrm{L}$ \\
LD & 6.25 & $2.0-4.2$ & $\mu \mathrm{kat} / \mathrm{L}$ \\
CRP & 79.3 & $0-6$ & $\mathrm{mg} / \mathrm{L}$ \\
IgG & 33.9 & $7-16$ & $\mathrm{~g} / \mathrm{L}$ \\
IgG4 & 19.1 & $0.061-1.21$ & $\mathrm{~g} / \mathrm{L}$ \\
\hline Abbrei & & & \\
\hline
\end{tabular}

Abbreviations: WBC, white blood cell; $\mathrm{Hb}$, hemoblobin; AST, aspartate aminotransferase; ALT, alanine aminotransferase; BUN, blood urea nitrogen; $\mathrm{CK}$, creatine kinase; LD, lactate dehydrogenase; CPR, C-reactive protein; IgG, Immunoglobulin G; IgG4, Immunoglobulin G4.

mopathy.

The patient underwent a BM study because of unexplained thrombocytopenia with reversed albumin to globulin ratio. The BM aspirates showed increased number of plasma cells, which included immature forms (16.8\% of plasma cells among the BM nucleated cells; Fig. 1B), as well as moderate eosinophilic hyperplasia (20.4\% of eosinophils among the BM nucleated cells; Fig. 1C and D). The cellularity varied with an average of $50 \%$. IHC staining of the BM biopsy showed increased numbers of CD138-positive plasma cells with interstitial and clustered infiltration; however, clonal restriction for kappa or lambda light chains was not observed. IgG and IgG4 stains showed increased numbers of IgG- and IgG4-positive plasma cells; 31 IgG4-positive plasma cells/HPF and 35 IgG-positive plasma cells/HPF were observed (IgG4/lgG-positive plasma cell ratio $=0.88$; Fig. $1 \mathrm{E}$ and $\mathrm{F}$ ). IgH gene rearrangement with $\mathrm{BM}$ aspirate was not found.
Flow cytometric immunophenotyping was performed using a FACSCanto II flow cytometer (BD Biosciences, San Jose, CA, USA) and a CD38/CD138/CD19/CD45/CD56 panel. Plasma cells in the PB comprised $0.376 \%$ of the WBCs $(62,040$ cells/ $\mathrm{mL}$ ); $58.3 \%$ of plasma cells were atypical plasma cells (low CD19 expression with $\left.\mathrm{CD}^{2} 8^{+} / \mathrm{CD} 138^{\mathrm{dim}} / \mathrm{CD}^{-} 6^{-} / \mathrm{CD}^{2} 5^{+}\right)$. The immunophenotype of the atypical plasma cells in the BM $(64.3 \%$ of the total BM plasma cells) was $\mathrm{CD} 38^{+} / \mathrm{CD} 138^{+} / \mathrm{CD} 56^{+} / \mathrm{CD}$ $19^{\text {low }} / C D 45^{\text {low }}$, slightly different from that of the PB cells (Fig. $1 G$ and $\mathrm{H}$ ). The difference in CD56 expression between PB and BM plasma cells is likely due to the nature of plasma cells in IgG4-RD. Among the heterogeneous plasma cells, only a few CD56-negative cells might migrate to the circulating system, as CD56 acts as an adhesion molecule. The patient was treated with high-dose steroids and discharged as his symptoms improved.

As IgG4-RD tends to form tumefactive lesions, patients are easily suspected of having malignancies. Additionally, BM findings can mimic other hematologic diseases such as lymphomas, plasma cell neoplasms, and histiocytic disorders. However, IgG4-RD diagnosis is difficult based on BM studies because the core pathological features are rarely present in the BM. Therefore, if a patient suspected of having IgG4-RD has an abnormal complete blood count, a BM study with IHC staining for CD138, kappa and lambda light chains, IgG, and IgG4 and flow cytometric immunophenotyping of plasma cells in the PB and BM aspirates should be considered. Furthermore, when a patient undergoes a BM study for lymphoma workup and diagnosis of plasma cell neoplasms or histiocytic disorders, hematopathologists should consider the possibility of IgG4-RD with BM involvement, if elevated serum IgG and IgG4 concentrations or other laboratory abnormalities are present.

\section{ACKNOWLEDGEMENTS}

None.

\section{AUTHOR CONTRIBUTIONS}

All authors have accepted their responsibility for the entire content of this manuscript and approved submission.

\section{CONFLICTS OF INTEREST}

No potential conflicts of interest relevant to this paper were reported. 
Kim HJ, et al.

$\mathrm{BM}$ and flow cytometric findings in IgG4-RD
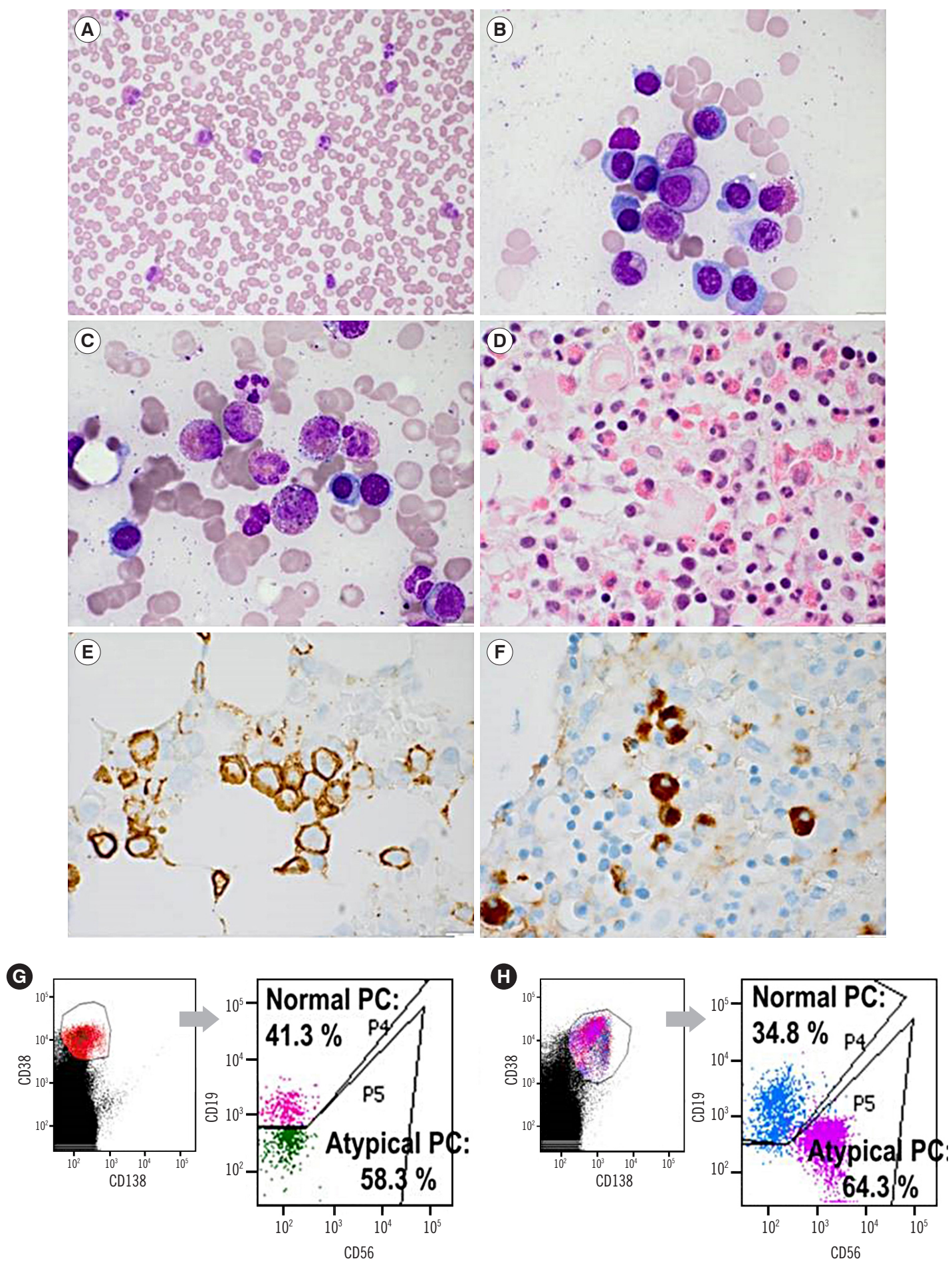

Fig. 1. Morphologic and IHC findings of PB and BM samples, and flow cytometric immunophenotyping of PC. (A) Eosinophilia, poikilocytosis (schistocytes and spherocytes), and rouleaux formation (PB, Wright stain, $\times 400$ ). (B) Increased numbers of PC including immature forms with slightly high NC ratio, nucleolus, and perinuclear halo (BM aspirate, Wright stain, $\times 1,000)$. (C) Increased number of eosinophils (BM aspirate, Wright stain, $\times 1,000$ ). (D) Increased number of eosinophils and PC (BM biopsy, H \& E stain, $\times 400$ ). (E) Increased number of PC (BM clot section, IHC stain for CD138, ×1,000). (F) Increased numbers of IgG4+ PC (BM biopsy, IHC stain for IgG4, ×1,000). (G, H) Presence of atypical PC with the immunophenotypes CD38 $/$ CD138 ${ }^{\mathrm{dim}} / \mathrm{CD} 56^{-} / \mathrm{CD} 19^{\text {low }} / \mathrm{CD} 45^{+}$in $\mathrm{PB}$ and $\mathrm{CD} 38^{+} / \mathrm{CD} 138^{+} / \mathrm{CD} 56^{+} / \mathrm{CD} 19^{\text {low }} / \mathrm{CD} 45^{\text {low }}$ in BM aspirates.

Abbreviations: IHC, immunohistochemistry; PB, peripheral blood; BM, bone marrow; PC, plasma cells. 


\section{RESEARCH FUNDING}

None declared.

\section{ORCID}

Han Joo Kim

Eunkyoung You

https://orcid.org/0000-0002-0088-0488

Seokchan Hong https://orcid.org/0000-0002-6836-499X

https://orcid.org/0000-0001-8722-3124

Chan-Jeoung Park

\section{REFERENCES}

1. Kamisawa T, Zen Y, Pillai S, Stone JH. IgG4-related disease. Lancet 2015;385:1460-71.

2. Moutsopoulos HM, Fragoulis GE, Stone JH. Diagnosis and differential diagnosis of IgG4-related disease https://www.uptodate.com/contents/ diagnosis-and-differential-diagnosis-of-igg4-related-disease (Updated

on 20th May, 2019).

3. Stone JH, Zen Y, Deshpande V. IgG4-related disease. N Engl J Med 2012;366:539-51.

4. Umehara H, Okazaki K, Masaki Y, Kawano M, Yamamoto M, Saeki T, et al. Comprehensive diagnostic criteria for IgG4-related disease (IgG4RD), 2011. Mod Rheumatol 2012;22:21-30.

5. Wallace ZS, Mattoo H, Carruthers M, Mahajan VS, Della Torre E, Lee H, et al. Plasmablasts as a biomarker for lgG4-related disease, independent of serum IgG4 concentrations. Ann Rheum Dis 2015;74:190-5.

6. Mattoo H, Mahajan VS, Della-Torre E, Sekigami Y, Carruthers M, Wallace ZS, et al. De novo oligoclonal expansions of circulating plasmablasts in active and relapsing IgG4-related disease. J Allergy Clin Immunol 2014;134:679-87.

7. Ichiki A, Hashimoto N, Ueda T, Hiraiwa S, Tajiri T, Nakamura N, et al. IgG4-related disease with bone marrow involvement. Intern Med 2016; 55:2295-9.

8. van den Elshout-den Uyl D, Spoto CPE, de Boer M, Leiner T, Leavis HL, Leguit RJ. First report of IgG4 related disease primary presenting as vertebral bone marrow lesions. Front Immunol 2019;10:1910.

9. Hwang SM, Paik JH, Lee JY. ImmunoglobulinG4-related disease mimicking lymphoma. Ann Hematol 2019;98:2239-41. 